\title{
MENINGKATKAN PRESTASI BELAJAR BAHASA BALI MELALUI PENERAPAN STRATEGI GUIDED TEACHING DAN STRATEGI TUTOR SEBAYA SISWA KELAS VIII A SMP NEGERI 6 DENPASAR
}

\section{IMPROVING BALI LEARNING ACHIEVEMENT THROUGH THE APPLICATION OF THE GUIDED TEACHING STRATEGY AND THE TUTOR'S STRATEGY AS CLASS VIII A STUDENTS OF SMP NEGERI 6 DENPASAR}

\author{
I Nengah Wijana* \\ SMP Negeri 6 Denpasar, Denpasar, Bali, Indonesia \\ *Email Penulis korespondensi: wijanainengah@gmail.co.id
}

\begin{abstract}
Abstrak
Penelitian tindakan kelas yang dilaksanakan bertujuan meningkatkan prestasi belajar Bahasa Bali siswa VIII A semester II tahun pelajaran 2018/2019 SMP Negeri 6 Denpasar melalui penerapan strategi guided teaching dengan strategi tutor sebaya. Penelitian dilaksanakan dalam dua siklus, di mana masing-masingmasing siklus terdiri dari tahap perencanaan, pelaksanaan, pengamatan, dan refleksi. Siklus I terdiri dari tiga kali pertemuan, demikian pula halnya dengan Siklus II. Data prestasi belajar peserta didik digali dengan tes prestasi belajar. Hasil penelitian menunjukkan bahwa prestasi belajar Bahasa Bali mengalami peningkatan ini terbukti dari data yang berhasil diperoleh yaitu dari hasil tes awal yang dilakukan nilai rata-rata prestasi belajar Bahasa Bali baru mencapai 72,78 dengan ketuntasan belajar 31,11\% pada siklus I mengalami peningkatan menjadi 78,24 dengan ketuntasan belajar 77,78\%. Pada siklus II setelah dilakukan penyempurnaan perlakuan dari kekurangan yang ditemukan pada siklus sebelumnya prestasi belajar Bahasa Bali meningkat menjadi 84,22 dengan ketuntasan belajar 97,78\%. Hal itu menandakan bahwa model pembelajaran yang diterapkan telah berhasil meningkatkan prestasi belajar Bahasa Bali.
\end{abstract}

Kata-Kata Kunci: Prestasi Belajar; Strategi Guided Teaching; Strategi Tutor Sebaya

\begin{abstract}
The classroom action research carried out aims to improve the learning achievement of Balinese VIII A students in the second semester of the 2018/2019 academic year at SMP Negeri 6 Denpasar through the application of guided teaching strategies with peer tutoring strategies. The research was carried out in two cycles, where each cycle consisted of planning, implementation, observation, and reflection stages. Cycle I consisted of three meetings, as well as Cycle II. Students' learning achievement data is explored by means of a learning achievement test. The results showed that learning achievement in Balinese has increased as evidenced by the data that was obtained, namely from the results of the initial test conducted, the average value of learning achievement in Balinese only reached 72.78 with learning mastery of $31.11 \%$ in the first cycle which increased to 78.24 with a learning completeness of $77.78 \%$. In the second cycle, after completing the treatment of the deficiencies found in the previous cycle, Balinese language learning achievement increased to 84.22 with a learning completeness of $97.78 \%$. This indicates that the learning model applied has succeeded in increasing the achievement of learning Balinese.
\end{abstract}

Keywords: Learning Achievement; Guided Teaching Strategy; Peer Tutor Strategy

\section{PENDAHULUAN}

Hasil kegiatan para ahli pendidikan merupakan harapan-harapan dipihak guru sudah dituangkan dalam Peraturan-peraturan yang ada, seperti termuat dalam Permen No. 41 Tahun 2007, Permen No. 65 Tahun 2013, Permen 81 A Tahun 2013 menuntut adanya perubahan cara mengajar guru agar aktif, insprinsif, menyenangkan, menantang, membangun prakarsa serta mampu menumbuhkan motivasinya agar peserta didik mampu menguasai materi pelajaran. Harapan tersebut dalam pelaksanaannya di lapangan tidaklah semudah yang diharapkan. Menurut H.D. Iriyanto (2012: 44), pendidikan bukanlah seperti mengisi ember 
kosong, tetapi seperti menyalakan api yang hampir padam. Kesuksesan tersebut lebih bergantung pada kemampuan seseorang memahami diri sendiri, kemampuan mengelola diri sendiri secara efektif, kemampuan untuk memahami orang lain dan kemampuan untuk mengelola hubungan dengan orang lain.

Untuk dapat memenuhi harapan-harapan yang telah disampaikan harus didukung dengan pengetahuan dan pemahaman guru mengenai strategi, metode, teknik, pendekatanpendekatan pembelajaran. Fakta yang ada di lapangan bahwa guru tidak mampu memenuhi semua harapan tersebut. Ini terbukti dari data lapangan terhadap tes yang diberikan pada siswa kelas VIII A semester II tahun pelajaran 2018/2019 SMP Negeri 6 Denpasar. Hasilnya adalah nilai rata-rata yang diperoleh baru mencapai 72,78 dengan ketuntasan belajar $31,11 \%$.

Apa yang menjadi harapan dunia pendidikan bagi guru dalam melaksanakan proses belajar mengajar ternyata belum sesuai. Banyak faktor yang menjadi penyebab tidak terwujudnya harapan tersebut, seperti: kurangnya kemauan guru mencoba model-model pembelajaran yang konstruktivis, kemampuan guru memahami metode-metode dan modelmodel pembelajaran, kemampuan guru melaksanakan teori-teori pembelajaran terbaru, kemampuan guru memahami karakteristik peserta didik, kelengkapan sarana prasarana yang ada di sekolah. Kemampuan siswa mengikuti proses pembelajaran, kebiasaan peserta didik yang sulit melupakan kegiatan bermain dan lain-lain.

Fakta yang ada dilapangan ternyata sulit bagi guru untuk memenuhi semua harapan, data juga sudah disampaikan berupa nilai siswa. Tidak sesuainya pelaksanaan proses belajar mengajar yang dilakukan guru menimbulkan kesenjangan. Oleh karenanya peneliti sebagai guru Bahasa Bali yang mengajar di kelas VIII A semester II tahun pelajaran 2018/2019 SMP Negeri 6 Denpasar mengupayakan peningkatan prestasi belajar Bahasa Bali dengan usaha maksimal melalui penerapan strategi guided teaching dan strategi tutor sebaya yang dilakukan mengikuti alur-alur pemikiaran para ahli dewasa ini. Dengan tindakan yang seperti itu diharapkan prestasi belajar peserta didik akan dapat ditingkatkan. Mengingat masalah ini adalah masalah yang mendesak untuk dipecahkan maka penelitian ini menjadi penting untuk dilaksanakan sesuai rencana dengan mengikuti masukan-masukan yang disarankan oleh teman-teman guru sejawat.

Sehubungan dengan ketentuan penyusunan rumusan masalah yang pada dasarnya merupakan suatu pertanyaan dari kenyataan yang ada dan harapan yang diinginkan, maka masalah yang dapat peneliti rumuskan untuk penelitian ini adalah: Apakah penerapan strategi guided teaching dan strategi tutor sebaya dapat meningkatkan prestasi belajar Bahasa Bali siswa kelas VIII A semester II tahun pelajaran 2018/2019 SMP Negeri 6 Denpasar? Upaya untuk memperbaiki praktek dalam pembelajaran agar lebih berkualitas dalam prosesnya, agar lebih meningkat hasil belajar yang diperoleh siswa menjadi tujuan dari penelitian ini dan dirumuskan sebagai berikut: Untuk meningkatkan prestasi belajar Bahasa Bali siswa kelas VIII A semester II tahun pelajaran 2018/2019 SMP Negeri 6 Denpasar dengan penerapan strategi guided teaching dan strategi tutor sebaya. Manfaat dari penelitian ini adalah: secara teori dapat memperkaya khasanah keilmuan dalam peningkatan kognitif siswa dan secara praktek akan bermanfaat: 1) Bagi guru, memiliki kemampuan pengajaran dengan model pembelajaran yang baru. Di samping itu, menambah wawasan tentang stimulasi yang tepat dalam merangsang dan meningkatkan kemampuan siswa yang mendorong guru lebih kreatif dalam menciptakan beragam media dan kegiatan sesuai situasi dan kebutuhan. 2) Bagi siswa memiliki kemampuan memahami dengan berbagai kegiatan yang menyenangkan namun tetap bermakna dalam rangka mengembangkan kemampuan mereka, misalnya siswa mampu berpikir kritis terhadap masalah yang didengarnya dalam pergaulan sehari-hari. 3) Bagi sekolah, meningkatkan mutu pendidikan secara umum, sekaligus meningkatkan mutu sekolah. 
Menurut Moh. Surya (2004:75), yaitu "prestasi belajar adalah hasil belajar atau perubahan tingkah laku yang menyangkut ilmu pengetahuan, keterampilan dan sikap setelah melalui proses tertentu, sebagai hasil pengalaman individu dalam interaksi dengan lingkungannya".

Menurut Tirtonegoro (2016) prestasi belajar adalah hasil dari pengukuran dan penilaian usaha belajar. Prestasi belajar siswa adalah hasil yang dicapai oleh seorang siswa dalam beiajarnya. Keberhasiian dari belajar ini dapat dilihat dari adanya perubahan ke hal yang lebih bask atau bertambahnya kecakapan atau keahliannya.

Menurut Nurkancana (2015 : 62) mengemukakan bahwa prestasi belajar adalah hasil yang telah dicapai atau diperoleh siswa berupa nilai mata pelajaran. Ditambahkan bahwa prestasi belajar merupakan hasil yang mengakibatkan perubahan dalam diri individu sebagai hasil dari aktivitas dalam belajar.

Taxonomy Bloom dan Simpson (Nana Syaodih Sukmadinata, 2017: 180-182) menyusun suatu tujuan belajar yang harus dicapai oleh seseorang yang belajar, sehingga terjadi perubahan dalam dirinya. Perubahan terjadi pada tiga ranah, yaitu: a) Ranah Kognitif, tentang hasil berupa pengetahuan, kemampuan dan kemahiran intelektual. Terdiri dari: 1) pengetahuan; 2) pemahaman; 3) penerapan; 4) analisa; 5) sintesa dan 6) evaluasi. b) Ranah Afektif, tentang hasil belajar yang berhubungan dengan perasaan sikap, minat, dan nilai. Terdiri dari : 1) penerimaan; 2) partisipasi; 3) penilaian; 4) organisasi; dan 5) pembentukan pola hidup. c) Ranah Psikomotorik, tentang kemampuan fisik seperti ketrampilan motorik dan syaraf, manipulasi objek, dan koordinasi syaraf. Terdiri dari: 1) persepsi; 2) kesiapan; 3) gerakan terbimbing; 4) gerakan yang terbiasa; 5) gerakan yang komplek; dan 6) kreativitas.

Dari pendapat para ahli diatas dapat disimpulkan bahwa prestasi belajar adalah perubahan tingkah laku mencakup tiga aspek (kognitif, afektif dan motorik) seperti penguasaan, penggunaan dan penilaian berbagai pengetahuan dan ketrampilan sebagai akibat atau hasil dari proses belajar dengan faktor-faktor yang mempengaruhinya yang tertuang dalam bentuk nilai yang di berikan oleh guru.

Belajar menurut Ugi Suprayogi (2017: 144) memiliki prinsip-prinsip, diantaranya: a) Belajar harus memiliki tujuan; b) Tujuan harus berhubungan dengan kebutuhan hidup; c) Dalam belajar harus ada usaha dan bersedia mengalami bermacam-macam kesukaran; d) Harus ada perubahan tingkah laku sebagai hasil; e) Harus ada hasil sambilan disamping tujuan pokok; f) Harus berbuat (learning by doing); g) Belajar sebagai suatu keseluruhan; h) Ada unsur bantuan dan bimbingan dari orang lain; i) Memerlukan insight; j) Ada tujuan lain disamping tujuan yang sebenarnya; k) Belajar dikatakan berhasil apabila memberi sukses yang menyenangkan; 1) Pengulangan dan latihan perlu diberikan atas dasar pemahaman; dan m) Ada kemauan untuk belajar.

Slameto (2015: 3) berpendapat ciri-ciri perubahan tingkah laku sebagai hasil belajar adalah: 1) perubahan secara sadar; 2) perubahan bersifat kontinyu dan fungsional; 3) perubahan bersifat positif dan aktif; 4) perubahan bukan bersikap sementara; 5) perubahan bertujuan dan terarah, serta 6) perubahan mencakup seluruh aspek tingkah laku.

Menurut Muhibbin Syah (2015: 145) faktor-faktor yang mempengaruhi belajar menjadi 3 macam, yaitu : 1) faktor internal, yang meliputi keadaan jasmani dan rohani siswa, 2) faktor eksternal yang merupakan kondisi lingkungan di sekitar siswa, dan 3) faktor pendekatan belajar yang merupakan jenis upaya belajar siswa yang meliputi strategi dan metode yang digunakan siswa untuk melakukan kegiatan mempelajari materi-materi pelajaran.

Guided teaching tidak hanya menginginkan siswa untuk belajar keterampilan dan isi akademik, namun juga beberapa aspek kehidupan. Pembelajaran seperti ini dicirikan oleh struktur tugas, tujuan dan penghargaan aktif yang melahirkan sifat ketergantungan yang 
positif antar sesama siswa, penerimaan perbedaan individu dan mengembangkan keterampilan bekerjasama antar kelompok. Kondisi ini akan memberikan konstribusi yang cukup berarti untuk membantu siswa yang mengalami kesulitan dalam memahami materi. Pada akhirnya siswa di dalam kelas dapat mencapai hasil belajar yang maksimal.

Menurut Hisyam Zaini (2018: 37 ) "Guided Teaching" ini adalah "strategi bertanya kepada peserta didik satu atau dua pertanyaan untuk mengetahui tingkat pemahaman peserta didik atau untuk memperoleh kesimpulan kemudian membaginya kepada kategori". "Guided Teaching" merupakan salah satu tipe kooperatif, tujuan pembelajaran kooperatif itu sendiri antara lain : meningkatkan motivasi belajar siswa, meningkatkan prestasi siswa, menumbuhkan sikap saling menghormati dan bekerja sama, menumbuhkan sikap tanggung jawab dan mampu menyelesaikan masalah dengan cara yang lebih baik.

Menurut Silberman (2016:116) Guided Teaching merupakan satu Model pembelajaran aktif yaitu kegiatan belajar mengajar dengan cara guru menanyakan satu atau lebih pertanyaan untuk membuka pengetahuan mata pelajaran atau mendapatkan hipotesis atau kesimpulan mereka dan kemudian memilahnya ke dalam kategori-kategori. Selain itu, Guided Teaching menjadi salah satu alternatif pembelajaran yang mengarah pada pemahaman konsep.

Kelebihan metode "Guided Teaching" adalah: (1) Menciptakan suasana belajar yang aktif; (2) Motivasi dan semangat belajar siswa meningkat; dan (3) Materi belajar yang disampaikan guru mampu menarik perhatian siswa. Sedang kelemahan dari metode "Guided Teaching" adalah: (1) Diperlukan bimbingan dari guru untuk melakukan kegiatan; (2) Waktu yang tersedia perlu dimanfaatkan dengan baik agar waktu yang ada tidak terbuang sia-sia; dan (3) Guru memerlukan persiapan dengan matang seperti persiapan bahan dan alat yang memadai.

Langkah-langkah "Guided Teaching” menurut Hisyam Zaini dan kawan-kawan (2008 : 37) meliputi: (1) Menyampaikan beberapa pertanyaan kepada peserta didik untuk mengetahui dan kemampuan yang mereka miliki. Gunakan pertanyaan-pertanyaan yamg mempunyai beberapa kemungkinan jawaban; (2) Memberikan waktu beberapa menit untuk menjawab pertanyaan. Anjurkan mereka untuk bekerja berdua atau dalam kelompok kecil; (3) Meminta peserta didik menyampaikan hasil jawaban mereka dan catatan jawaban-jawaban yang mereka sampaikan. Jika memungkinkan tulis di papan tulis dengan mengelompokkan jawaban mereka dalam kategori-kategori yang nantinya akan anda sampaikan dalam kegiatan belajar; (4) Menyampaikan poin-poin utama dari materi anda dengan ceramah yang interaktif; dan (5) Meminta peserta didik untuk membandingkan jawaban mereka dengan poin-poin yang telah anda sampaikan. Catatan poin-poin yang dapat memperluas bahasan materi anda.

Tutor sebaya adalah teman sebaya yang lebih pandai, dan tutor kakak adalah tutor dari kelas yang lebih tinggi. Bahasa teman sebaya lebih mudah dipahami, selain itu dengan teman sebaya tidak ada rasa segan, rendah diri, malu, dan sebagainya sehingga diharapkan siswa yang kurang paham tidak segan-segan untuk mengungkapkan kesulitan-kesulitan yang dihadapi (Suherman, 2003 : 277). Menurut Ischak dan warji dalam Suherman (2003:276) berpendapat bahwa "Tutor sebaya adalah sekelompok siswa yang telah tuntas terhadap bahan pelajaran, memberi bantuan kepada siswa yang mengalami kesulitan dalam memahami bahan pelajaran yang dipelajarinya". Mengingat bahwa siswa adalah unsur pokok dalam pengajaran yang pada akhirnya dapat mengubah tingkah lakunya sesuai dengan yang diharapkan.

Strategi Tutor Sebaya akan menghidupkan suasana yang kompetitif, sehingga setiap kelompok akan terus terpacu untuk menjadi kelompok yang terbaik. Oleh karena itu, selain aktivitas anggota kelompok, peran ketua kelompok atau tutor sangat besar pengaruhnya terhadap keberhasilan kelompok dalam mempelajari materi ajar yang disajikan. Ketua kelompok dipilih secara demokratis oleh seluruh siswa. Misalnya, jika di suatu kelas terdapat 
46 siswa, berarti ada 9 kelompok dengan catatan ada satu kelompok yang terdiri atas 6 siswa. Sebelum diskusi kelompok terbentuk, siswa perlu mengajukan calon tutor. Seorang tutor hendaknya memiliki kriteria: (1) memiliki kemampuan akademis di atas rata-rata siswa satu kelas; (2) mampu menjalin kerja sama dengan sesama siswa; (3) memiliki motivasi tinggi untuk meraih prestasi akademis yang baik; (4) memiliki sikap toleransi dan tenggang rasa dengan sesama; (5) memiliki motivasi tinggi untuk menjadikan kelompok diskusinya sebagai yang terbaik; (6) bersikap rendah hati, pemberani, dan bertanggung jawab; dan (7) suka membantu sesamanya yang mengalami kesulitan (Azizah, 2014: 19).

Tahap-tahap persiapan dengan menggunakan pendekatan tutor sebaya adalah sebagai berikut: (1) Guru membuat program pengajaran satu pokok bahasan yang dirancang dalam bentuk penggalan-penggalan sub pokok bahasan. Setiap penggalan satu pertemuan yang didalamnya mencakup judul penggalan tujuan pembelajaran, khususnya petunjuk pelaksanaan tugas-tugas yang harus diselesaikan. (2) Menentukan beberapa orang siswa yang memenuhi kriteria sebagai tutor sebaya. Jumlah tutor sebaya yang di tunjuk disesuaikan dengan jumlah kelompok yang dibentuk. (3) Mengadakan latihan bagi para tutor. Dalam pelaksanaan tutorial atau bimbingan ini, siswa yang menjadi tutor bertindak sebagai guru.Sehingga latihan yang diadakan oleh guru merupakan semacam pendidikan guru atau siswa itu. Latihan di adakan dengan dua cara yaitu melalui latihan kelompok kecil dimana dalam hal ini yang mendapatkan latihan hanya siswa yang akan menjadi tutor, dan melalui latihan klasikal, dimana siswa seluruh kelas dilatih bagaimana proses pembimbingan ini berlangsung. (4) Pengelompokan siswa dalam kelompok-kelompok kecil yang yang terdiri atas 4-6 orang. Kelompok ini disusun berdasarkan variasi tingkat kecerdasan siswa. Kemudian tutor sebaya yang telah ditunjuk di sebar pada masing-masing kelompok yang telah ditentukan (Sabarudin, 2016: 13).

\section{METODE PENELITIAN}

Untuk jelasnya dimana penelitian dilakukan maka perlu disampaikan bahwa penelitian ini dilakukan di SMP Negeri 6 Denpasar yang beralamat di Jalan Gurita, Sesetan Denpasar. Sekolah ini lingkungannya asri, indang, rindang, dan aman. Demi kebenaran arah penelitian maka peneliti memilih sebuah rancangan penelitian yang dibuat oleh oleh Arikunto, Suharsimi, 2007.

Subjek penelitian ini adalah siswa kelas VIII A semester II tahun pelajaran 2018/2019 SMP Negeri 6 Denpasar yang berjumlah 45 orang. Objek penelitian tindakan kelas adalah peningkatan prestasi belajar Bahasa Bali siswa kelas VIII A semester II tahun pelajaran 2018/2019 SMP Negeri 6 Denpasar setelah penerapan strategi guided teaching dan strategi tutor sebaya. Bulan Juli sampai bulan Nopember tahun 2018 adalah jadwal pelaksanaan penelitian tindakan kelas ini. Untuk memecahkan masalah dalam penelitian diperlukan data yang relevan dengan permasalahannya, sedangkan untuk mendapatkan data tersebut perlu digunakan teknik pengumpulan data. Pengumpulan data dilakukan dengan observasi menggunakan tes prestasi belajar. Dalam pelaksanaan PTK, analisis data diwakili oleh momen refleksi putaran penelitian tindakan. Refleksi yang dilakukan peneliti akan membantu dalam menafsirkan datanya. Data dalam penelitian ini dianalisis dengan analisis deskriptif kuantitatif, berupa rata-rata dan presentase, serta pembandingan dengan indikator keberhasilan penelitian, juga dilakukan penyajian data dengan menyusun tabel dan grafik 


\section{HASIL DAN PEMBAHASAN}

Gambaran yang diperoleh dari kegiatan awal yaitu dari 45 siswa kelas VIII A semester II tahun pelajaran 2018/2019 SMP Negeri 6 Denpasar hanya 6 siswa $(13,33 \%)$ memperoleh nilai di atas KKM, 8 siswa $(17,78 \%)$ memperoleh nilai sama dengan KKM sedangkan yang lainnya yang jumlahnya 31 siswa $(68,89 \%)$ memperoleh nilai di bawah KKM. Data tersebut menunjukkan rendahnya prestasi belajar Bahasa Bali. Berdasarkan data tersebut akhirnya peneliti memilih model para ahli untuk digunakan pada siklus selanjutnya.

Hasil yang diperoleh dari tindakan Siklus I yang dilakukan adalah: 22 siswa $(48,89 \%)$ memperoleh nilai di atas KKM, 13 siswa $(28,89 \%)$ memperoleh nilai sama dengan KKM dan 10 siswa $(22,22 \%)$ memperoleh nilai di bawah KKM. Dari penelitian tersebut ketuntasan belajar yang dicapai baru 77,78\%. Rata-rata (mean) sebesar 78,24. Median (titik tengahnya) sebesar 78,24. Modus sebesar 80,00

Tabel 1. Data Kelas Interval Siklus I

\begin{tabular}{ccccc}
\hline $\begin{array}{c}\text { No } \\
\text { Urut }\end{array}$ & Interval & $\begin{array}{c}\text { Nilai } \\
\text { Tengah }\end{array}$ & $\begin{array}{c}\text { Frekuensi } \\
\text { Absolut }\end{array}$ & $\begin{array}{c}\text { Frekuensi } \\
\text { Relatif }\end{array}$ \\
\hline 1 & $70-72$ & 71 & 6 & 13,33 \\
2 & $73-75$ & 74 & 4 & 8,89 \\
3 & $76-78$ & 77 & 0 & 0,00 \\
4 & $79-81$ & 80 & 32 & 71,11 \\
5 & $82-84$ & 83 & 1 & 2,22 \\
6 & $85-87$ & 86 & 2 & 4,44 \\
\hline & Total & & 45 & 100 \\
\hline
\end{tabular}

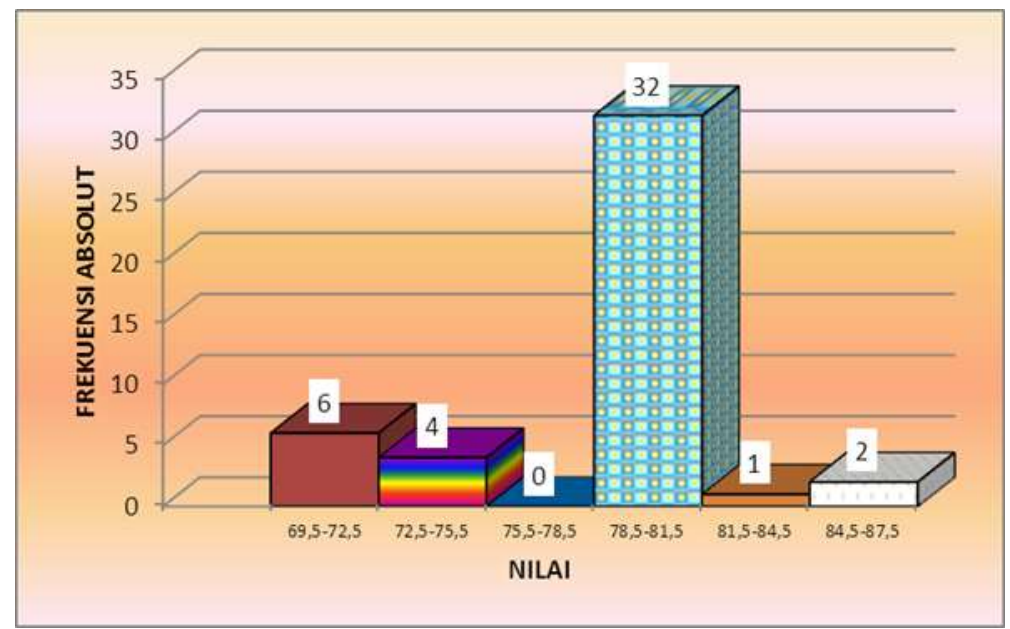

Gambar 1. Histogram Siklus I

Kekurangan-kekurangan yang ditemukan: 1) Jumlah kelompok terlalu besar, pelaksanaan pembelajaran membutuhkan waktu yang lama karena media yang dibuat belum memenuhi kriteria untuk mewakili keinginan siswa. 2) Ikatan pertemanan belum terjalin erat sehingga menjadi penghambat dalam menumbuhkan motivasi, keyakinan dan keberanian dalam diri peserta didik. 3) Guru belum menemukan cara untuk menumbuhkan ikatan emosi dengan cepat agar siswa mampu menguasai materi yang disampaikan dan mampu menerapkannya dalam kehidupan sehari-hari. 4) Penyajian yang dilakukan belum maksimal karena peneliti baru mencoba model yang digunakan. 
Kelebihan yang ada adalah: 1) Peneliti telah berupaya keras untuk menyiapkan bahan pembelajaran agar perkembangan peserta didik membaik. 2) Pengelolaan kelas sudah diupayakan dan bimbingan terhadap siswa juga sudah dilakukan dengan maksimal. 3) Untuk validasi data, guru telah mengajak teman sejawat untuk mengamati proses pembelajaran.

Hasil yang diperoleh dari penilaian terhadap tes prestasi belajar siklus II dapat dijelaskan: 39 siswa $(86,67 \%)$ memperoleh nilai di atas KKM yang artinya kemampuan mereka dalam menerpa ilmu sudah sangat baik, melebihi indikator yang ditetapkan, 5 siswa $(11,11 \%)$ memperoleh nilai sama dengan KKM. Sedangkan masih ada seorang siswa (2,22\%) memperoleh nilai di bawah KKM atau belum mencapai KKM rata-rata pelajaran Bahasa Bali. Semua kekurangan-kekurangan yang ada sudah diperbaiki pada siklus ini, sehingga tidak perlu lagi ada keragu-raguan bahwa penerapan strategi guided teaching dan strategi tutor sebaya mampu meningkatkan prestasi belajar Bahasa Bali sesuai harapan. Indikato ryang dituntut untuk diselesaikan tidak ada lagi yang tertinggal. Semua hasil yang diperoleh pada Siklus II ini menunjukkan bahwa penelitian ini tidak perlu dilanjutkan lagi ke siklus berikutnya. Rata-rata (mean) sebesar 84,22. Median sebesar 85,00. Modus sebesar 80,00 .

Tabel 2. Data Kelas Interval Siklus II

\begin{tabular}{ccccc}
\hline $\begin{array}{c}\text { No } \\
\text { Urut }\end{array}$ & Interval & $\begin{array}{c}\text { Nilai } \\
\text { Tengah }\end{array}$ & $\begin{array}{c}\text { Frekuensi } \\
\text { Absolut }\end{array}$ & $\begin{array}{c}\text { Frekuensi } \\
\text { Relatif }\end{array}$ \\
\hline 1 & $77-79$ & 78 & 6 & 13,33 \\
2 & $80-82$ & 81 & 13 & 28,89 \\
3 & $83-85$ & 84 & 6 & 13,33 \\
4 & $86-88$ & 87 & 19 & 42,22 \\
5 & $89-91$ & 90 & 1 & 2,22 \\
6 & $92-94$ & 93 & 0 & 0,00 \\
\hline & Total & & 45 & 100 \\
\hline
\end{tabular}

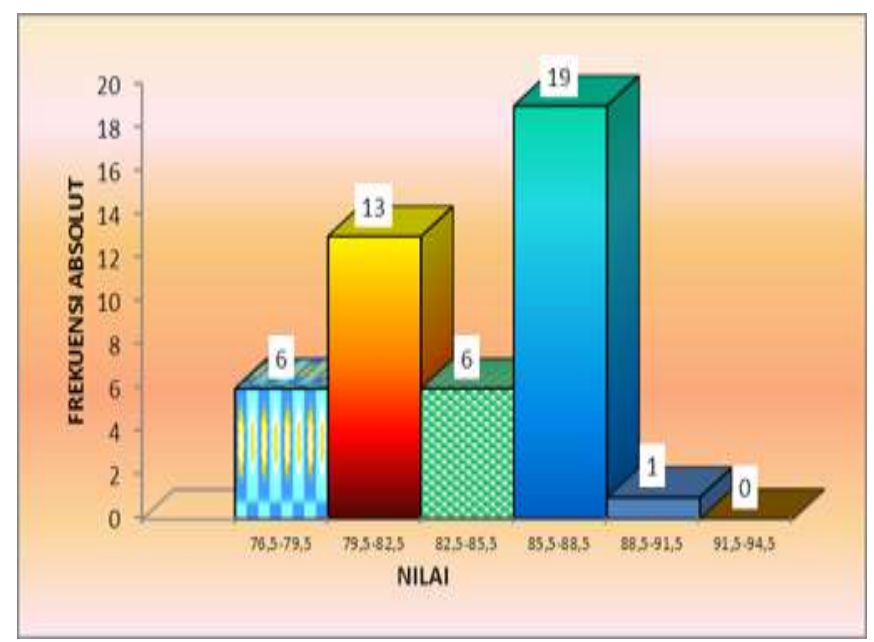

Gambar 2. Histogram Siklus II

Pelaksanaan proses pembelajaran menuntut adanya peningkatan prestasi sesuai harapan. Untuk itu usaha yang maksimal harus dilakukan dengan giat karena pencapaian peningkatan prestasi tidak gampang untuk untuk dicapai, perlu upaya-upaya, contoh-contoh yang benar, perlu waktu untuk melatih diri.dengan belum maksimalnya hal ini dilakukan maka hasil yang diperoleh pada awalnya menunjukkan rendahnya prestasi belajar Bahasa Bali yang baru memperoleh rata-rata 72,78 dengan ketuntasan belajar 31,11\% adalah akibat 
banyak faktor baik pada faktor siswa itu sendiri, faktor guru dan faktor alat yang kurang memadai. Setelah giat melakukan pembaikan pada siklus I terlihat adanya kemajuan yaitu prestasi belajar Bahasa Bali sudah mencapai rata-rata 78,24 dengan ketuntasan belajar mencapai $77,78 \%$. Walaupun hasil sudah dapat dicapai seperti itu namun perolehan hasil tersebut belum memenuhi indikator keberhasilan penelitian yang menuntut minimal $85 \%$ siswa mampu mencapai ketuntasan belajar sesuai harapan. Oleh karenanya pelaksanaan penelitian dilanjutkan ke siklus II.

Pada siklus II banyak perbaikan proses pembelajaran sudah dilakukan seperti memberikan demonstrasi yang lebih baik dengan contoh-contoh yang lebih banyak, menyuruh peserta didik mencoba mengulang-ulang gerakan yang benar dengan guru giat memotivasi, memberi arahan-arahan serta tuntunan-tuntunan agar prestasi belajar mereka bisa meningkat. Dengan upaya tersebut akhirnya hasil yang diperoleh di siklus II menunjukkan peningkatan dengan rata-rata 84,22 dan ketuntasan belajar 97,78\%. Dengan hasil akhir yang didapat pada siklus II ini maka tujuan penelitian sesuai dengan indikator keberhasilan penelitian sudah dapat dicapai. Oleh karenanya penelitian ini sudah dianggap berhasil dan tidak dilanjutkan ke siklus berikutnya

\section{KESIMPULAN DAN SARAN}

Penerapan strategi guided teaching dan strategi tutor sebaya dalam proses pembelajaran mampu membuat pembelajaran menjadi bermakna, mampu menuntaskan prestasi belajar siswa dapat memahami pembelajaran dengan lebih baik materi yang disampaikan. Semua fakta di atas dapat dibuktikan dengan data: 1) Kegiatan awal nilai ratarata baru mencapai 72,78 dengan ketuntasan belajar 31,11\%. 2) Siklus I mengalami peningkatan menjadi 78,24 dengan ketuntasan belajar 77,78\%. 3) Siklus II prestasi belajar Bahasa Bali meningkat menjadi 84,22 dengan ketuntasan belajar 97,78\%.

Jadi dapat disimpulkan bahwa penerapan strategi guided teaching dengan strategi tutor sebaya dapat meningkatkan prestasi belajar Bahasa Bali siswa VIII A semester II tahun pelajaran 2018/2019 SMP Negeri 6 Denpasar.

Bukti keberhasilan penelitian yang telah disampaikan menjadi pedoman peneliti untuk menyampaikan saran sebagai berikut: 1) Bagi guru, disarankan menggunakan strategi yang sesuai dengan materi yang akan diajarkan dan melakukan analisis materi pelajaran yang akan disampaikan serta berperan dalam mendampingi siswa ketika proses pembelajaran berlangsung. 2) Bagi peneliti, untuk penelitian selanjutnya disarankan melakukan penelitianpenelitian yang berikutnya dengan lingkup mata pelajaran dan materi-materi pelajaran yang lebih luas lagi. 3) Siswa diharapkan mampu berperan aktif dalam kegiatan pembelajaran. Dengan terlibat aktif dalam pembelajaran tentu akan meningkatkan hasil belajarnya, selain pada penilaian kognitif tetapi juga pada penilaian afektif.

\section{UCAPAN TERIMAKASIH}

Ucapan terima kasih disampaikan kepada Kepala SMP Negeri 6 Denpasar dan Bapak/Ibu Guru SMP Negeri 6 Denpasar

\section{DAFTAR PUSTAKA}

Azizah, Rizka. 2014. Skripsi. Pengaruh Model Pembelajaran Tutor Sebaya Terhadap Hasil Belajar Matematika. Jurusan Pendidikan Matematika Fakultas Ilmu Tarbiyah Dan Keguruan Universitas Islam Negeri Syarif Hidayatullah Jakarta. 
Badan Standar Nasional Pendidikan. 2007. Peraturan Menteri Pendidikan Nasional Republik Indonesia Nomor 41 Tahun 2007. Jakarta: BSNP.

Hisyam Zaini 2018. Strategi Pembelajaran Aktif. Yogyakarta : Insan Madani

Iriyanto, H.D. 2012. Hebat Gurunya Dahsyat Muridnya. Jakarta: Erlangga.

Mohamad Surya. 2004. Psikologi Pembelajaran dan Pengajaran. Bandung: Pustaka Bani Quraisy.

Muhibbin Syah. 2015. Psikologi Pendidikan dengan Pendekatan Baru, Bandung: Remaja Rosdakaya Offset

Nurkancana, Wayan. 2015. Evaluasi Pendidikan. Penerbit: Surabaya : Usaha Nasional

Sabaruddin, 2016. Skripsi. Peranan Metode Tutor Sebaya Dalam Meningkatkan Hasil Belajar Siswa Kelas 5 SDN Inpres Karawa Kab. Pinrang Pada Pokok Bahasan KPK dan FPB. Fakultas Ilmu Pendidikan Universitas Negeri Makassar.

Silberman, Melvin L.. 2016. Active learning : 101 Cara Belajar Siswa Aktif. Nusamedia, Bandung

Slameto. 2015. Belajar dan Faktor-Faktor yang Mempengaruhinya. Jakarta : PT. Rineka Cipta.

Suherman, Erman, dkk. 2003. Strategi Pembelajaran Matematika Konten Porer. Universitas Pendidikan Indonesia.

Suprayogi, Ugi. 2017. Pendidikan Usia Lanjut. Ilmu dan Aplikasi Pendidikan Bagian 4 Pendidikan Lintas Bidang. Tim Pengembang Ilmu Pendidikan FIP-UPI. Penerbit: PT Imperial Bhakti Utama. Bandung., PH. 2004. MBS, Life Skill, KBK, CTL dan Saling Keterkaitannya. Makalah yang Disampaikan pada Semiloka DBEP di NTB dan Bali.

Syaodih Sukmadinata, Nana. 2017. Metode Penelitian Pendidikan, Bandung: Remaja Rosda Karya.

Tirtonegoro, Sutratinah. 2016. Penelitian Hasil Belajar Mengajar. Surabaya: Usaha Nasional. 